\title{
Utilization of crown pineapple waste as raw material preparation of activated carbon as adsorbent in natural gas storage
}

\author{
Yuliusman ${ }^{1, *}$, Nasruddin $^{2}, H$ I Naf' an $^{1}, J$ Sinto $^{1}$, and $Y W$ Nugroho $^{1}$ \\ ${ }^{1}$ Chemical Engineering Department, University of Indonesia, Kampus Baru UI Depok, Indonesia \\ ${ }^{2}$ Mechnanical Engineering Department, University of Indonesia, Kampus Baru UI Depok, Indonesia
}

\begin{abstract}
Activated carbon used as natural gas storage in adsorbed natural gas technology due to physical adsorption properties. Pineapple crown was used as raw material for activated carbon by reason of high lignocellulose content. The purpose of this study is to produce high surface area of activated carbon with high carbon composition (up to $80 \%$ weight). Activated carbon were prepared through chemical activation using $\mathrm{KOH}$ with various weight ratio and physical activation using $\mathrm{N}_{2}$ with $150 \mathrm{ml} / \mathrm{min}$ flowrate. Carbonization of pineapple crown is done at $350^{\circ} \mathrm{C}$ followed by chemical activation with $\mathrm{KOH}$ activator and physical activation. The result of iod number indicate the 1:1 weight $\mathrm{KOH}$ ratio gave the highest iod number $1337 \mathrm{mg} / \mathrm{mg}$ and $1190.799 \mathrm{~m}^{2} / \mathrm{g}$ surface area achieved by chemical-physical activation.
\end{abstract}

\section{Introduction}

Energy demand in Indonesia raise every year in each sector up to $3.99 \%$ from 2000 to 2014 [1]. Natural gas has huge potential to supply this demand in Indonesia due to high potential stock up to 103.35 billion barrels in 2016 [1]. Natural gas can be store as Compressed Natural Gas (CNG) or Liquefied Natural Gas (LNG). However, CNG requires high pressure and specialised vessel which can handle up to $>250$ bar whereas LNG requires extreme low temperature $\left(-161^{\circ} \mathrm{C}\right)$ and regasification plant. Both of $\mathrm{CNG}$ and $\mathrm{LNG}$ has some serious safety factor and additional equipment. To overcome this technology, Adsorbed Natural Gas (ANG) developed. ANG is technology to store natural gas using adsorbent in cylinder vessel, commonly activated carbon used as adsorbent in ANG. This technology allows to store natural gas in low pressure $(30-40$ bar) but has high capacity in same vessel as CNG [2].

Activated carbon can be manufactured from agricultural waste which has high alpha cellulose content, such as pineapple crown. The amount of pineapple production in 2015 is 1,729,00 tonnes and projected to increase with $6.97 \%$ or $1,850,00$ tonnes in 2016 [3]. With a huge of pineapple production can be predicted there is huge of pineapple crown waste per harvest.

Table 1. Chemical Compound of Pineapple Crown.

\begin{tabular}{cc}
\hline Chemical Compound & Content (weight \%) \\
\hline Alpha Cellulose & $69.5-71.5$ \\
\hline
\end{tabular}

* Corresponding author: usman@,che.ui,ac,id

\begin{tabular}{cc}
\hline Pentosan & $17.0-17.8$ \\
Lignin & $4.4-4.7$ \\
Pectin & $1.0-1.2$ \\
Fat and Wax & $3.3-3.0$ \\
Ash & $0.71-0.87$ \\
Another comp. & $4.5-5.3$ \\
\hline
\end{tabular}

Activated carbon can be produced through carbonization and activation. Carbonization use high temperature $\left(600^{\circ} \mathrm{C}\right)$ to remove all volatile substance [4]. Activation using two methods, chemical activation and physical activation. In chemical activation there is wet activation which mean the soaked first with some activating agent $\left(\mathrm{HNO}_{3}, \mathrm{ZnCl}_{2}, \mathrm{H}_{3} \mathrm{PO}_{4}, \mathrm{NaOH}, \mathrm{H}_{2} \mathrm{SO}_{4}\right.$, and $\mathrm{KOH}$ ) [4] then treating with heat to activate the chemical activation. Activating agent used to bond with volatile substance. Physical activation often called as dry activation since its thermal treatment $\left(800^{\circ} \mathrm{C}-1000^{\circ} \mathrm{C}\right)$ only using several gasses $\left(\mathrm{N}_{2}, \mathrm{CO}_{2}\right.$, and vapour).

The usage of $\mathrm{KOH}$ as an activating agent can produced activated carbon with surface area 1255.88 $\mathrm{m}^{2} / \mathrm{g}$ [5] while using $\mathrm{NaOH}$ can produce $907 \mathrm{~m}^{2} / \mathrm{g}$ [6] and using $\mathrm{ZnCl}_{2}$ can produce $1100 \mathrm{~m}^{2} / \mathrm{g}$ [7]. For physical activation using $\mathrm{N}_{2}$ can produce surface area 593,08 $\mathrm{m}^{2} / \mathrm{g}$ on other hand using, $\mathrm{CO}_{2}$ can produce surface area 558 $\mathrm{m}^{2} / \mathrm{g}[8]$.

Therefore, this research utilized activating agent $\mathrm{KOH}$ for chemical activation and $\mathrm{N}_{2}$ for physical activation in the production of activated carbon from pineapple crown. 


\section{Experimental}

\subsection{Carbonization}

In the research, dried pineapple crown was entering the muffle furnace on the temperature of $350^{\circ} \mathrm{C}$ for 1 hour. Pineapple crown then shattered using mortar to smaller sized particle and increase the surface area for reacted with activating agent in chemical activation process.

\subsection{Chemical and physical activation}

A certain amount of charcoal pineapple crown was soaked with $\mathrm{KOH}$ at the weight ratio 1:0.25, 1:0.5, $1: 0.75$, and $1: 1$. The mixture was dehydrated and mixing on hot plate magnetic stirrer at $100^{\circ} \mathrm{C}$ for 1 hour with stirring speed of $100 \mathrm{rpm}$. The dehydrated sample then filtered and washed with $\mathrm{HCl} 0.01 \mathrm{~N}$ for achieve neutral $\mathrm{pH}$, then washed several times with distilled water. The neutral sample dried in oven at $105^{\circ} \mathrm{C}$ for 2 hours.

The dried sample from chemical activation then physically activated by using channelled $\mathrm{N}_{2}$ gas at 150 $\mathrm{ml} /$ minute on $350^{\circ} \mathrm{C}$ for 1 hour. The product was cooled in room temperature then shattered again using mortar.

Characterization of carbon surface area using iod number method.

\section{Result and discussion}

\subsection{Carbonization of pineapple crown}

The process occurs in $350^{\circ} \mathrm{C}$ for 1 hour due to trial with different temperature. Temperature $400^{\circ} \mathrm{C}$ cause a lot of ashes and tar, while at $300^{\circ} \mathrm{C}$ carbonization not happened due to the brownish product which is not show any sign of black carbon. From the Table 2 . carbonization process had average yield percentage of $36 \%$. From the yield percentage it shows lot of volatile matters contained on pineapple crown.

Table 2. Pineapple crown carbonization yield.

\begin{tabular}{|c|c|c|}
\hline Initial mass (g) & Final mass (g) & Yield (\%) \\
\hline 2.7 & 0.9 & 33.3 \\
\hline 2.6 & 1 & 38.5 \\
\hline 2.5 & 0.9 & 36 \\
\hline 2.4 & 0.9 & 37.5 \\
\hline 2.3 & 0.8 & 34.7 \\
\hline \multicolumn{2}{|c|}{ Average } & 36 \\
\hline
\end{tabular}

\subsection{Chemical activation with $\mathrm{KOH}$}

$\mathrm{KOH}$ was used due to its ability to open the pores of the carbon from carbonization process. The process occurs in $100^{\circ} \mathrm{C}$ to evaporate the water content and help $\mathrm{KOH}$ to impregnate the carbon, the previous shattered process creates a large surface area hence the $\mathrm{KOH}$ can have reacted more with carbon. The following reaction of $\mathrm{KOH}$ with carbon showed below

$$
\begin{gathered}
4 \mathrm{KOH}+\mathrm{C} \rightarrow 4 \mathrm{~K}+\mathrm{CO}_{2}+2 \mathrm{H}_{2} \mathrm{O} \\
6 \mathrm{KOH}+\mathrm{C} \rightarrow 2 \mathrm{~K}+3 \mathrm{H}_{2}+\mathrm{K}_{2} \mathrm{CO}_{3} \\
4 \mathrm{KOH}+2 \mathrm{CO}_{2} \rightarrow 2 \mathrm{~K}_{2} \mathrm{CO}_{3}+2 \mathrm{H}_{2} \mathrm{O}
\end{gathered}
$$

$\mathrm{KOH}$ will disperse to all carbon surface which cause partial oxidation with carbon particle. Carbon will have reacted with oxygen will turn into $\mathrm{CO}_{2}$ gasses on mixing process occurs. The $\mathrm{CO}_{2}$ and carbonate appear as product in reaction, presence of $\mathrm{CO}_{2}$ proofed by bubble that exist while the reaction process occurs while carbonate shows as white as chalk, in substance the carbonate dissolved, and the $\mathrm{CO}_{2}$ diffused. $\mathrm{KOH}$ attend as strong base and corrosive will cause more ashes to come off from carbon. [9].

Table 3. shows the effect of $\mathrm{KOH}$ weight ratio to yield. More $\mathrm{KOH}$ ratio will reduce the yield of carbon hence the $\mathrm{KOH}$ lead to carbon destruction into micro and nano particle and its cause less carbon to filtered.

Table 3. Chemical activation process yield.

\begin{tabular}{cccc}
\hline $\begin{array}{c}\text { KOH } \\
\text { ratio }\end{array}$ & Initial mass (g) & Final mass (g) & Yield (\%) \\
\hline 0.25 & 15 & 13.8 & 92 \\
0.5 & 15 & 12.6 & 84 \\
0.75 & 15 & 12.2 & 81 \\
1 & 15 & 10.6 & 68 \\
\hline
\end{tabular}

\subsection{Physical activation with $\mathrm{N}_{2}$}

Activated carbon from chemical activation were proceed with physical activation. The process occurs in $350^{\circ} \mathrm{C}$ for 1 hour. $\mathrm{N}_{2}$ passes the column with $150 \mathrm{ml} /$ minute flow rate. $\mathrm{N}_{2}$ as inert gas will change the any gasses from the column hence the carbon will free from any volatile substance and impurities. The yield from physical activation showed in Table 4 .

Table 4. Physical activation process yield.

\begin{tabular}{cccc}
\hline $\begin{array}{c}\text { KOH } \\
\text { ratio }\end{array}$ & Initial mass (g) & Final mass (g) & Yield (\%) \\
\hline 0.25 & 11.9 & 9.4 & 78.9 \\
0.5 & 11.1 & 9.1 & 81.9 \\
0.75 & 10.6 & 9.6 & 90.6 \\
1 & 9.3 & 9.1 & 97.8 \\
\hline
\end{tabular}

More $\mathrm{KOH}$ ratio will gain more yield due to less volatile substance presence in previous process. The physical activation carries any volatile and impurities from activated carbon with thermal treatment and $\mathrm{N}_{2}$ as inert gas.

\subsection{Surface area from activation process}

Activated carbon surface area can be observed towards iodine number. Activated carbon ability to adsorb iodine indicate ability to adsorb component with low molecular 
weight [10]. Activated carbon with high iod number has larger surface area.

\subsubsection{Chemical activation}

The effect of higher $\mathrm{KOH}$ weight ratio will give higher surface area, the $\mathrm{KOH}$ lead to deform the carbon into smaller particle and create more pores. Smaller particle and more pores gives more surface area. The effect of $\mathrm{KOH}$ ratio to iod number can be seen at Table 5. As mentioned before, the effect of $\mathrm{KOH}$ addition on chemical activation can cause less yield but can provide better surface area.

Table 5. Chemical activation iod number.

\begin{tabular}{cc}
\hline KOH ratio & Iod Number (mg/mg) \\
\hline 0.25 & 922 \\
0.5 & 956.6 \\
0.75 & 999 \\
1 & 1005 \\
\hline
\end{tabular}

\subsubsection{Physical activation}

Less $\mathrm{KOH}$ ratio will cause more volatile left in carbon and less pores created. The physical activation carries any volatile left and impurities from previous process. The effect of $\mathrm{KOH}$ ratio to iod number can be seen at Table 6 .

Table 6. Physical activation iod number.

\begin{tabular}{cc}
\hline KOH ratio & Iod Number $(\mathbf{m g} / \mathbf{m g})$ \\
\hline 0.25 & 1205 \\
0.5 & 1239 \\
0.75 & 1259.5 \\
1 & 1337 \\
\hline
\end{tabular}

\subsection{Scanning electron microscopy (SEM) result}

Scanning electron microscopy was conducting to see every activated carbon process from carbonization, chemical activation and physical activation. SEM analysis using JEOL JED - 2300 Analysis Station Plus. The SEM characterization result can be seen at Figure 1, Figure 2, and Figure 3.

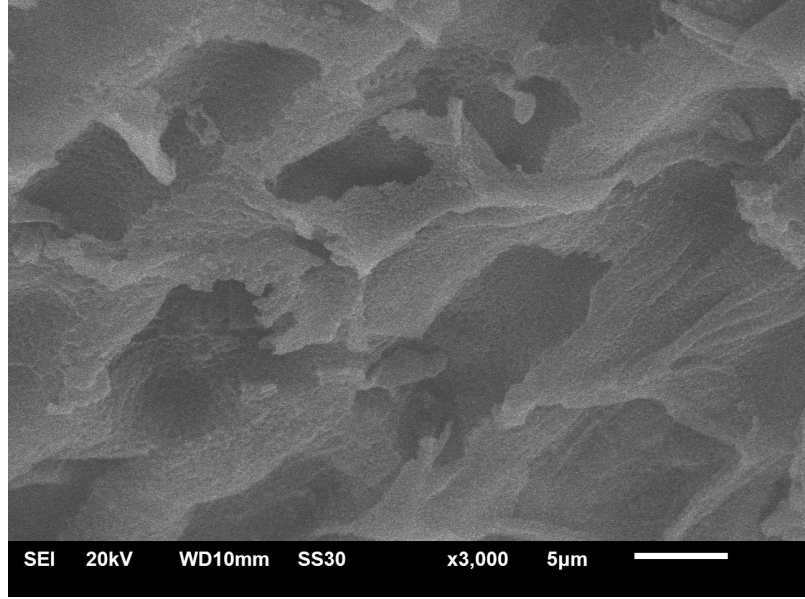

Fig. 1. SEM of carbonization in 3000 magnifications.

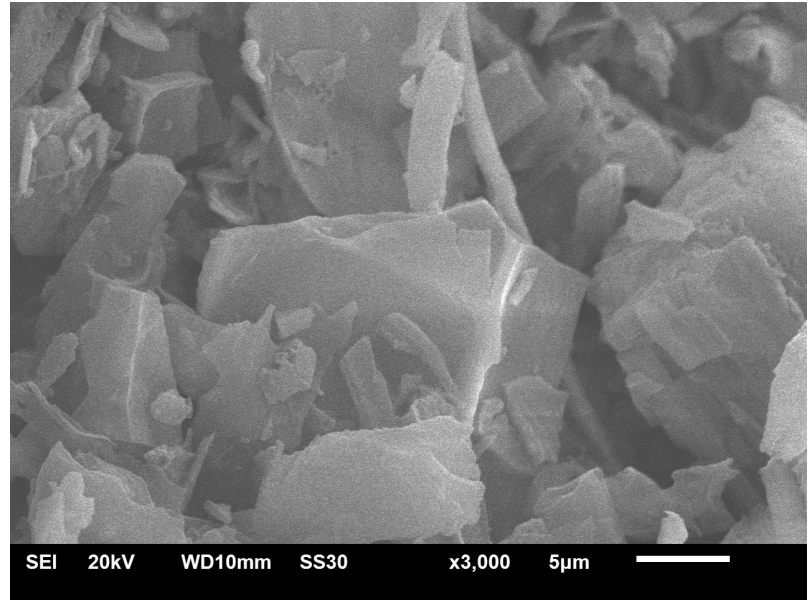

Fig. 2. SEM of chemical activation in 3000 magnifications.

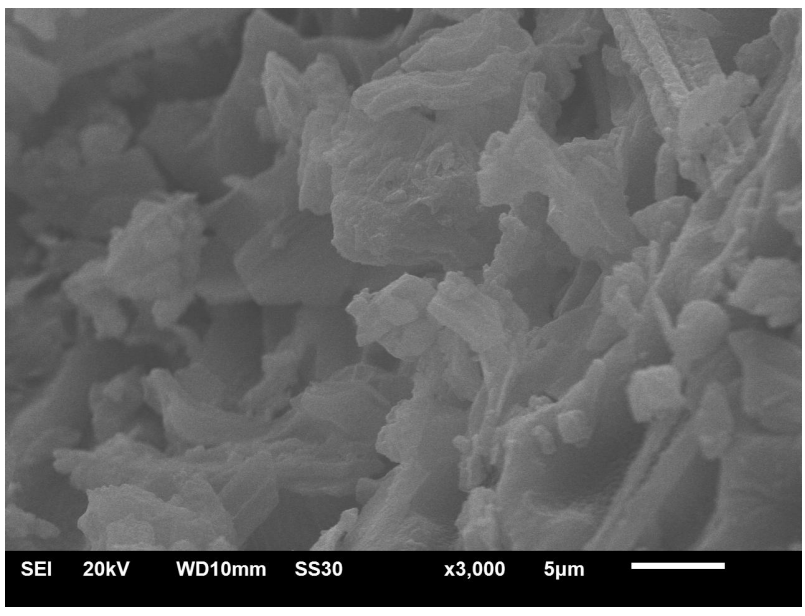

Fig. 3. SEM of physical activation in 3000 magnifications.

The Figure 1 shows the complex of pineapple crown leaf which has cell wall and sturdy structure. The thermal treatment on pineapple crown not affect the cell wall bond. Figure 2 show the pineapple crown which already treated with $\mathrm{KOH}$ 1:1 has crumbling structure due to $\mathrm{KOH}$ property which tent to deform the cell wall. Figure 3 show the product of chemical activation and 
physical activation from pineapple crown. The structure become more crumbling and smaller. Physical activation with thermal activation and $\mathrm{N}_{2}$ can create more flakes due to leaf structure that tend to preserve its shape.

\subsection{Energy Dispersive X-ray Spectroscopy (EDX) result}

Energy dispersive x-ray spectroscopy was conducting to see the composition of activated carbon in element. The Indonesia national standar of activated carbon has to showed carbon content at least $65 \%$. The EDX result can be seen at Table 7 .

Table 7. Physical activation process yield.

\begin{tabular}{cccc}
\hline Element & $\begin{array}{c}\text { Carbonization } \\
\text { product } \\
\text { (weight \%) }\end{array}$ & $\begin{array}{c}\text { Chemical } \\
\text { activation } \\
\text { product } \\
\text { (weight \%) }\end{array}$ & $\begin{array}{c}\text { Physical } \\
\text { activation } \\
\text { product } \\
\text { (weight \%) }\end{array}$ \\
\hline $\mathrm{C}$ & 81.64 & 71.73 & 81.93 \\
$\mathrm{O}$ & 13.39 & 8.64 & 14.88 \\
$\mathrm{Mg}$ & 0.46 & 0.76 & 0.77 \\
$\mathrm{Cl}$ & 0.45 & - & - \\
$\mathrm{K}$ & 4.15 & 8.59 & 1.98 \\
$\mathrm{Si}$ & - & 0.96 & - \\
$\mathrm{Ca}$ & - & 3.08 & 0.43 \\
$\mathrm{Cu}$ & - & 3.13 & - \\
$\mathrm{Zn}$ & - & 3.11 & - \\
\hline
\end{tabular}

From the Table 7. the dominant composition of activated carbon from pineapple crown are $\mathrm{C}, \mathrm{O}, \mathrm{Mg}$, and $\mathrm{K} . \mathrm{C}$ and $\mathrm{O}$ become the main component of leaf structure and the rest of it are depend on where the plant grows. Soil nutrient contribute to how much ion composition on leaf as the place to do photosynthesis process.

The carbon composition in chemical activation lower in percentage because there is high $\mathrm{K}$ presence due to $\mathrm{KOH}$ as activating agent and another element as the result of washing treatment, the carbon composition begins to raise after physical activation due to thermal and gas treatment which has ability to carry out some impurities and volatile substance in activated carbon.

\subsection{Brunauer-Emmett-Teller (BET) result}

Brunaeur-Emmett-Teller was conducting to see the surface area of activated carbon using Quantachrome Instruments version 11.0. Activated carbon tested by BET instruments is activated carbon which has through chemical activation using $\mathrm{KOH} 1: 1$ and physical activation. The result has surface area is $1190.799 \mathrm{~m}^{2} / \mathrm{g}$.

\section{Conclusion}

From the research results and analysis, we can conclude the activated carbon from pineapple crown has huge potential to be mass production and has met the
Indonesian Industrial Standard. $\mathrm{KOH}$ as activating agent can improve the pore size and give high surface area. Physical activation has huge contribute to create new pores and carry out volatile substance. From chemical activation using $\mathrm{KOH}$ 1:1 weight ratio and physical activation using $\mathrm{N}_{2}$ produced activated carbon with surface area of $1337 \mathrm{mg} / \mathrm{mg}$ with $81.93 \%$ carbon content.

The research was funded by "Hibah PITTA Mahasiswa Universitas Indonesia 2018" from Directorate Research and Community Service Universitas Indonesia. The author declares no competing interests or any conflicts of financial interest.

\section{References}

[1] BPPT Outlook Energi Indonesia 2016: Pengembangan Energi untuk Mendukung Industri Hijau (2016)

[2] Liu B, Wang W, Wang N, and Au. J. of Energy Chemistry 23 662-668 (2014)

[3] Kementrian Pertanian Outlook Nenas: Komoditas Pertanian Sub Sektor Hortikultura (2016)

[4] González-G P, Arenas-E D, Ávila-B D, Urones-G $\mathrm{E}$, and Otero-D L C J. of Colloid and Interface Sci. 490 410-419 (2017)

[5] Kurniawan, Alfin. Harsono, Frans C, and Ki O L Penyimpanan Gas Metana Sebagai Bahan Bakar dengan Teknologi ANG (Adsorbed Natural Gas) Menggunakan Limbah Kulit Ketela Pohon (2011)

[6] Schroder E, Thomauske K, Weber C, Hornung A and Tumiatti V J. Analysis Appl. Pyrolysis 79 10611 (2007)

[7] Yacob A R, Siti Z H, Vicinisvarri I and Ratna S D Nano tungsten carbide prepared from palm kernel shell for catalytic decomposition of hydrazine: Proc. Int. Conf. on Chemical, Biology and Environmental Eng. CBEE Singapore (2009)

[8] Pereria R G, Veloso C M, da Silva N M, de Seousa L F, Bonomo R C F, and Souza A O Fuel Process Technol 126 476-86 (2014)

[9] Erlina U, Budi E Pengaruh Konsentrasi Larutan $\mathrm{KOH}$ pada kabon aktif tempurung kelapa untuk adsorpsi logam $\mathrm{Cu}$. Prosiding Seminar Nasional Fisika (E-Journal) SNF2015. Universitas Negeri Jakarta (2015)

[10] Yuliusman et al IOP Conf. Ser.: Earth Environ. Sci. 75012009 (2017)

[11] Yuliusman et al IOP Conf. Ser.: Mater. Sci. Eng. 176012055 (2017)

[12] Yuliusman, Purwanto, W.W., Nugroho, Y.S., Smoke Clearing Method using Activated Carbon and Natural Zeolite. Int. J. of Technology 6(3) 492503 (2015) 